\title{
Colon or Rectum Neuroendocrine Tumor Clinical Distant Metastasis TNM Finding v7
}

National Cancer Institute

\section{Source}

National Cancer Institute. Colon or Rectum Neuroendocrine Tumor Clinical Distant

Metastasis TNM Finding v7. NCI Thesaurus. Code C90132.

A clinical finding about one or more characteristics of colon or rectum neuroendocrine tumor, following the rules of the TNM AJCC V7 classification system as they pertain to distant metastases. 